\title{
Effect of triclosan, triclocarban, 2,2',4,4'-tetrabromodiphenyl ether, and bisphenol A on the iodide uptake, thyroid peroxidase activity, and expression of genes involved in thyroid hormone synthesis
}

Yuanfeng Wu, Frederick A. Beland, and Jia-Long Fang *

Division of Biochemical Toxicology, National Center for Toxicological Research, Food and Drug Administration, Jefferson, AR 72079, USA

Running Title: Triclosan, triclocarban, BDE-47, and bisphenol A in thyroid hormone synthesis

* To whom correspondence should be addressed. Tel: +1-870-543-7612; Fax: +1-870-5437136; Email: jia-long.fang@fda.hhs.gov

The views presented in this article do not necessarily reflect those of the U.S. Food and Drug Administration.

\footnotetext{
(C) 2016. This manuscript version is made available under the Elsevier user license http://www.elsevier.com/open-access/userlicense/1.0/
} 


\title{
Keywords
}

Thyroid disruptors; iodide uptake; thyroid hormone synthesis; thyroid peroxidase

\begin{abstract}
$\underline{\text { Abstract }}$
Triclosan, triclocarban, 2,2',4,4'-tetrabromodiphenyl ether (BDE-47), and bisphenol A (BPA) have been reported to disturb thyroid hormone (TH) homeostasis. We have examined the effects of these chemicals on sodium/iodide symporter (NIS)-mediated iodide uptake and the expression of genes involved in TH synthesis in rat thyroid follicular FRTL5 cells, and on the activity of thyroid peroxidase (TPO) using rat thyroid microsomes. All four chemicals inhibited NIS-mediated iodide uptake in a concentration-dependent manner. A decrease in the iodide uptake was also observed in the absence of sodium iodide. Kinetic studies showed that all four chemicals were non-competitive inhibitors of NIS, with the order of $K_{i}$ values being triclosan $<$ triclocarban $<$ BDE-47 $<$ BPA. The transcriptional expression of three genes involved in TH synthesis, Slc5a5, Tpo, and Tgo, and three thyroid transcription factor genes, Pax8, Foxe1, and $N k x 2-1$, was examined using quantitative realtime PCR. No significant changes in the expression of any genes were observed with triclosan or triclocarban. BDE-47 decreased the level of Tpo, while BPA altered the expression of all six genes. Triclosan and triclocarban inhibited the activity of TPO at 166 and > $300 \mu \mathrm{M}$, respectively. Neither BDE-47 nor BPA affected TPO activity. In conclusion, triclosan, triclocarban, BDE-47, and BPA inhibited iodide uptake, but had differential effects on the expression of TH synthesis-related genes and the activity of TPO.
\end{abstract}




\section{Introduction}

Thyroid hormones (THs) regulate a number of physiological processes and are essential for the metabolism of proteins, fats, and carbohydrates, brain development, and body growth (Mullur et al., 2014). The maintenance of TH homeostasis and the proper execution of the biological functions of THs are critical for normal physical and mental development. Extensive research has identified a broad range of chemicals that disrupt thyroid function (Boas et al., 2006; Patrick, 2009). For instance, triclosan, triclocarban, 2,2',4,4'tetrabromodiphenyl ether (BDE-47), and bisphenol A (BPA) have been reported to be thyroid disruptors (Boas et al., 2006; Patrick, 2009). The fact that these four chemicals are commonly used and widely distributed in the environment warrants a deeper understanding of their thyroid disrupting effects and the underlying mechanisms.

Triclosan and triclocarban are two broad-spectrum anti-bacterial agents widely used in a variety of personal care products (Fang et al., 2010; Witorsch and Thomas, 2010). There is increasing evidence that triclosan disturbs the thyroid system in different experimental organisms. For instance, triclosan has been shown to alter postembryonic development in frogs (Marlatt et al., 2013) and to interfere with the thyroid axis in zebrafish (Pinto et al., 2013). A significant decrease in serum thyroxine (T4) levels was observed in rats orally exposed to triclosan at $\geq 100 \mathrm{mg} / \mathrm{kg}$ body weight for 4 days (Crofton et al., 2007; Paul et al., 2010) and in mice dermally administered triclosan at $\geq 27 \mathrm{mg} / \mathrm{kg}$ body weight for 90 days (Fang et al., 2015). Perinatal exposure to $300 \mathrm{mg}$ triclosan/kg body weight decreased both maternal and neonatal serum T4 levels in rats (Paul et al., 2012). Triclocarban has also been reported to alter the expression levels of TH responsive genes in rat pituitary cells (Hinther et al., 2011).

Polybrominated diphenyl ethers (PBDEs) are used commercially as fire retardants in a variety of consumer products. Many PBDE congeners have been detected in environmental samples and human tissues, with the predominant form being BDE-47 (Hites, 2004). A number of studies have demonstrated that short-term oral exposure to BDE-47 or DE-71, a commercial PBDE mixture containing BDE-47, at $\geq 10 \mathrm{mg} / \mathrm{kg}$ body weight decreased serum T4 levels in 
rats and mice (Hallgren et al., 2001; Richardson et al., 2008; Zhou et al., 2001). Exposing rats to BDE-47 or DE-71 during pregnancy and lactation also significantly reduced T4 levels in their offspring (Ellis-Hutchings et al., 2006; Szabo et al., 2009).

BPA is a high-production-volume chemical that is widely used as a monomer in the production of polycarbonate plastics and epoxy resins (Rubin, 2011). Perinatal exposure to BPA impaired the learning and memory ability of male offspring in mice and rats (Xu et al., 2010; Xu et al., 2007). Concomitantly, rat pups exhibited mild hyperthyroidism, as evidenced by an increase in the circulating concentration of T3 or T4 (Delclos et al., 2014; Xu et al., 2007; Zoeller et al., 2005). In addition, there is evidence that BPA acts as an antagonist of the human TH receptor and suppresses TH receptor-mediated transcription of target genes in vitro (Moriyama et al., 2002; Sheng et al., 2012; Zoeller et al., 2005).

Thyroid disruptors may act through several pathways, including altering TH synthesis, metabolism, and/or transport (Boas et al., 2006; Patrick, 2009). Efforts have been made to understand the mechanisms by which these chemicals interfere with the thyroid system in animals, with most attention being paid to TH metabolism and transport. The glucuronidation of TH, which is catalyzed by UDP glucuronosyltransferases, is one of the major metabolic pathways of TH (Wu et al., 2005). Triclosan, BDE-47, and PBDE mixtures have been reported to induce hepatic microsomal T4-glucuronidation activity and elevate the expression levels of UDP glucuronosyltransferases, which are believed to be responsible for their T4 decreasing effects in rodents (Paul et al., 2010; Richardson et al., 2008; Szabo et al., 2009; Zhou et al., 2001). Hydroxylated metabolites of BDE-47 have also been shown to compete with $\mathrm{T} 4$ for binding to the TH transport protein transtherytin and T4 binding globulin (Marchesini et al., 2008; Meerts et al., 2000). The hyperthyroidism induced by $\mathrm{BPA}$ in rodents has been hypothesized to result from the antagonist effect of BPA on the TH receptor, which leads to the loss of negative feedback regulating TH synthesis (Zoeller et al., 2005).

Previous studies with triclosan, triclocarban, BDE-47, and BPA have focused mainly on the 


\section{$\underline{\text { Materials and Methods }}$}

\section{Chemicals and reagents}

Triclosan [5-chloro-2-(2, 4-dichlorophenoxy) phenol, purity 99\%] was obtained from Alfa Aesar (Ward Hill, MA). BDE-47 (purity 99.5\%) was purchased from Chem Service (West Chester, PA). Triclocarban [3,4,4'-trichlorocarbanilide, purity 99\%], BPA (purity $\geq 99 \%$ ), Coon's modified Ham's F12 medium, insulin, hydrocortisone, Gly-His-Lys acetate, somatostatin, transferrin, TSH, ammonium cerium(IV) sulfate dihydrate, arsenic(III) oxide, sodium iodide $(\mathrm{NaI})$, sodium perchlorate $\left(\mathrm{NaClO}_{4}\right.$, purity $\left.\geq 98 \%\right)$, potassium hexafluorophosphate $\left(\mathrm{KPF}_{6}\right.$, purity $\left.\geq 98 \%\right)$, dimethyl sulfoxide (DMSO), thiazolyl blue 
tetrazolium bromide (MTT) were obtained from Sigma-Aldrich (St. Louis, MO). Penicillin-streptomycin solutions and 2.5\% trypsin were purchased from Fisher Scientific (Pittsburgh, PA). Fetal bovine serum (FBS) was acquired from Atlanta Biologicals (Lawrenceville, GA).

\section{Cell culture}

Rat thyroid follicular FRTL-5 cells were obtained from Sigma-Aldrich and cultured in Coon's modified Ham's F12 medium supplemented with $10 \mu \mathrm{g} / \mathrm{ml}$ insulin, $10 \mathrm{nM}$ hydrocortisone, 10 $\mathrm{ng} / \mathrm{ml}$ Gly-His-Lys acetate, $10 \mathrm{ng} / \mathrm{ml}$ somatostatin, $5 \mu \mathrm{g} / \mathrm{ml}$ transferrin, $10 \mathrm{mU} / \mathrm{ml} \mathrm{TSH}$, $5 \%$ FBS, and penicillin-streptomycin solution. The cells were maintained at $37^{\circ} \mathrm{C}$ in a humidified atmosphere with $5 \% \mathrm{CO}_{2}$.

\section{Iodide uptake assay}

Iodide uptake was determined using a non-radioactive Sandell-Kolthoff reaction-based colorimetric assay as described by Waltz et al. (Waltz et al., 2010) with minor modifications. FRTL-5 cells were treated in two ways. To determine the short-term effects on iodide uptake, FRTL-5 cells cultured in clear 96-well plates were washed with iodide uptake buffer (Hank's balanced salt solution supplemented with $10 \mathrm{mM}$ HEPES) and then incubated with various concentrations of the test chemicals in the presence of $10 \mu \mathrm{M} \mathrm{NaI}$ for $1 \mathrm{~h}$ or $5-40 \mu \mathrm{M} \mathrm{NaI}$ for $5 \mathrm{~min}$. A series of chemical solutions with concentrations that were 100X of the final concentrations in the iodide uptake assay were prepared in DMSO (triclosan, triclocarban, BDE-47, and BPA) or water $\left(\mathrm{NaClO}_{4}\right.$ and $\left.\mathrm{KPF}_{6}\right)$, and stored at $-20^{\circ} \mathrm{C}$. For each well of the assay plate, $1 \mu \mathrm{l}$ of the 100X chemical solution was diluted in $89 \mu \mathrm{l}$ of iodide uptake buffer and was added to the assay plate using a 12-channel reservoir (USA Scientific, Orlando, FL). Immediately after that, $10 \mu \mathrm{l}$ of $\mathrm{NaI}(50-400 \mu \mathrm{M})$ was added to each well using a 12channel reservoir. To determine the long-term effects on iodide uptake, FRTL-5 cells were treated with various concentrations of the test chemicals for $24 \mathrm{or} 48 \mathrm{~h}$. At the end of the treatment, the culture medium containing the test chemicals was removed, and the cells were washed with uptake buffer and then incubated with $10 \mu \mathrm{M} \mathrm{NaI}$ for $1 \mathrm{~h}$. After the NaI incubation, cells were washed twice with ice cold uptake buffer and lysed in $100 \mu l$ water. A 
$100 \mu \mathrm{l}$ aliquot of $10.5 \mathrm{mM}$ ammonium cerium (IV) sulfate was added to each well, followed by the addition of $100 \mu \mathrm{l}$ of $24 \mathrm{mM}$ sodium arsenite (III). The plates were left to stand at room temperature for $10 \mathrm{~min}$, and the absorbance was then determined at $420 \mathrm{~nm}\left(\mathrm{~A}_{420}\right)$ using a BioTek Synergy 2 Plate Reader (BioTek, Winooski, VT). A set of wells containing known concentrations of NaI was included. The logarithm of $\mathrm{A}_{420}$ was plotted against the iodide content, and linear regression analysis was performed to obtain a standard curve.

\section{Cytotoxicity determination}

The effects of triclosan, triclocarban, BDE-47, and BPA on the growth of FRTL-5 cells were assessed using an MTT assay. Briefly, cells were plated into clear 96-well plates at cell densities of $5 \times 10^{4}$ cells/well for $48 \mathrm{~h}$ incubations and $3 \times 10^{4}$ cells/well for $72 \mathrm{~h}$ incubations. The cells were allowed to attach to the bottom of the wells for $24 \mathrm{~h}$ before being treated with $0.03,0.1,0.3,1,3,10,30,100$, and $300 \mu \mathrm{M}$ test chemical for 24 or $48 \mathrm{~h}$. Control cells were fed with complete culture medium containing $0.1 \%$ (v/v) DMSO, which had no effect on cell growth. At the end of the treatment, MTT assays were performed as previously described (Wu et al., 2015).

\section{RNA isolation and real-time PCR}

FRTL-5 cells were treated with various concentrations of triclosan, triclocarban, BDE-47, or BPA for 6,24 , or $48 \mathrm{~h}$. At the end of the treatment, total RNA was isolated from the FRTL-5 cells using an RNeasy Mini kit (Qiagen, Hilden, Germany) and reverse transcribed into cDNA using a SuperScript III first-strand synthesis system (Life Technologies, Carlsbad, CA) following the manufacturer's instructions. Real-time PCR was performed using SsoAdvanced Universal SYBR Green Supermix (Bio-Rad, Hercules, CA) on a BioRad CFX96 real-time PCR system. Pre-designed primers targeting rat Slc5a5 (encodes NIS, QT00183995), Tpo (encodes TPO, QT00194327), and Tg (encodes thyroglobulin, QT00182959), thyroid transcription factor genes Pax8 (QT00182945), Foxe1 (QT00395346), and Nkx2-1 (QT01599752), and the endogenous control glyceraldehyde 3phosphate dehydrogenase (Gapdh, QT00199633) were obtained from Qiagen. All samples were run in triplicate. Data were normalized for Gapdh and analyzed using the $\Delta \Delta \mathrm{Ct}$ 
method.

\section{Isolation of rat thyroid microsomes}

Rat thyroid microsomes were isolated as described by Paul et al. with minor modifications (Paul et al., 2014). Briefly, frozen thyroid glands, pooled from 40 normal healthy Wistar male rats, were homogenized in $2 \mathrm{ml}$ of ice-cold buffer $(5 \mathrm{mM}$ potassium phosphate, $200 \mathrm{mM}$ sucrose, $1 \mathrm{mM}$ EDTA, and $500 \mathrm{U} / \mathrm{ml}$ catalase) per $10 \mathrm{mg}$ of thyroid tissue. The homogenate was centrifuged at $800 \mathrm{~g}$ for $10 \mathrm{~min}$ at $4{ }^{\circ} \mathrm{C}$ to remove large debris and then ultracentrifuged at $100,000 \mathrm{~g}$ for $60 \mathrm{~min}$ at $4{ }^{\circ} \mathrm{C}$. The supernatant was discarded, and the pellet was resuspended in $250 \mu \mathrm{l}$ of homogenization buffer (without catalase) per $10 \mathrm{mg}$ of thyroid tissue. Glycerol (5\%) was added to the final microsomal preparation, and aliquots were stored at $-80{ }^{\circ} \mathrm{C}$. The protein concentration of the microsomal preparation was determined using a BCA Protein Assay kit (Thermo Scientific, Boston, MA).

\section{TPO activity assay}

The activity of TPO in rat thyroid microsomes was determined using Amplex UltraRed (AUR, Life Technologies) as described by Paul et al. with some modifications (Paul et al., 2014). The assay system contained $200 \mathrm{mM}$ potassium phosphate buffer, $12.5 \mu \mathrm{g}$ rat thyroid microsomal protein, $25 \mu \mathrm{M}$ AUR, $300 \mu \mathrm{M} \mathrm{H}_{2} \mathrm{O}_{2}$, and various concentrations of the test chemicals in a total volume of $200 \mu \mathrm{l}$. First, $150 \mu \mathrm{l}$ of potassium phosphate buffer containing thyroid microsomal protein and AUR was added to each well of a black 96-well plate, followed by the addition of $2 \mu \mathrm{l}$ of $100 \mathrm{X}$ test compound solutions (dissolved in DMSO). The reaction was initiated by adding $48 \mu \mathrm{l}$ of potassium phosphate buffer containing the desired concentration of $\mathrm{H}_{2} \mathrm{O}_{2}$. The test plates were shaken on a BioTek Synergy 2 Plate Reader for $30 \mathrm{~min}$, and the fluorescence was measured using 530/25 $\mathrm{nm}$ as the excitation filter and $590 / 35 \mathrm{~nm}$ as the emission filter.

\section{Data analysis}

Data are presented as the mean \pm standard deviation of three independent experiments. Comparisons amongst concentrations were conducted by one-way analysis of variance, with 
multiple comparisons versus the control group being performed by Dunnett's method. When necessary, the data were log transformed to maintain an equal variance or normal distribution. The results were considered significant at $P<0.05$.

\section{Results}

\section{Short-term effects of triclosan, triclocarban, BDE-47, and BPA on the iodide uptake in FRTL-5 cells}

The effects of triclosan, triclocarban, BDE-47, and BPA on the iodide uptake in FRTL-5 cells were determined in two different manners. The first was to examine whether or not these chemicals affected sodium/iodide symporter (NIS)-mediated iodide uptake by interacting with NIS. This was achieved by performing competition experiments, in which FRTL-5 cells were co-incubated with the test chemicals and NaI, the substrate of NIS, for a short period $(5 \mathrm{~min}-1 \mathrm{~h})$. Iodide uptake was determined using a non-radioactive assay, as described by Waltz et al. (Waltz et al., 2010). Following incubation with $10 \mu \mathrm{M} \mathrm{NaI}$ for 1 $\mathrm{h}$, iodide uptake was readily detected in the FRTL-5 cells (approximate 50 pmol iodide per well). The $\mathrm{IC}_{50}$ values of $\mathrm{NaClO}_{4}$ and $\mathrm{KPF}_{6}$, two well-known NIS inhibitors, were tested as positive control and gave values of 0.277 and $0.018 \mu \mathrm{M}$, respectively (Fig. 1), which were in agreement with the values reported by Waltz et al. (2010). The highest concentration of $\mathrm{NaClO}_{4}$ completely blocked iodide uptake in the FRTL-5 cells, suggesting that the observed iodide uptake was mainly mediated by NIS (Fig. 1). There was a concentrationdependent decrease in the iodide uptake by FRTL-5 cells when they were incubated with $\mathrm{NaI}$ in the presence of triclosan, triclocarban, BDE-47, or BPA. The inhibitory effects on iodide uptake were not believed due to cytotoxicity, because exposure to these concentrations of the test chemicals and $\mathrm{NaI}$ for such a short time (1 h) did not affect cell viability.

To examine further the kinetics of these NIS inhibitors, the non-radioactive iodide uptake assay was validated for its application in kinetic studies. As shown in Fig. 2A, an inverse linear correlation was observed between the logarithm of $\mathrm{A}_{420}$ and the iodide content from 0 - 
200 pmol. All the iodide levels obtained in the present study fell within this range. The timedependent iodide uptake was examined by incubating FRTL-5 cells with $10 \mu \mathrm{M} \mathrm{NaI}$ for $2-$ 120 min. Iodide uptake in the FRTL-5 cells increased in a linear manner during the first 10 min, and tended to saturate after $30 \mathrm{~min}$ of incubation (Fig. 2B). Based on these data, the initial velocity of iodide uptake was determined by incubating FRTL-5 cells with $5-320 \mu \mathrm{M}$ $\mathrm{NaI}$ for $5 \mathrm{~min}$ (Fig. 2C). A Lineweaver-Burk double-reciprocal plot revealed that it followed the Michaelis-Menten equation (Fig. 2D). The apparent $K_{m}$ for sodium iodide was $38.4 \mu \mathrm{M}$ (Fig. 2D), which is consistent with values previously reported in FRTL-5 cells (Kogai et al., 2000; Kosugi et al., 1996). These data demonstrated that the non-radioactive iodide uptake assay was appropriate for use in kinetic studies.

Next we examined the effect of triclosan, triclocarban, BDE-47, and BPA on the kinetics of iodide uptake in FRTL-5 cells. As shown in Fig. 3A, triclosan decreased the $V_{\max }$ in a concentration-dependent manner, whereas it had no significant effect on the $K_{m}$, indicating that triclosan inhibited NIS-mediated iodide uptake in a non-competitive manner. The slope of each line on the Lineweaver-Burk plot was plotted against the concentration of triclosan, which gave an inhibition constant $\left(K_{i}\right)$ of $21.3 \mu \mathrm{M}$ for triclosan (Fig. 3E). Similar effects were observed with triclocarban, BDE-47, and BPA, all of which inhibited iodide uptake in a non-competitive manner (Fig. 3B - 4D), with the $K_{i}$ values being 69.0, 77.8, and $112.3 \mu \mathrm{M}$ (Fig. 3F-4H), respectively.

\section{Long-term effects of triclosan, triclocarban, BDE-47, and BPA on the iodide uptake in FRTL-5 cells}

The long-term effects of triclosan, triclocarban, BDE-47, and BPA on the iodide uptake in FRTL-5 cells were determined by exposing FRTL-5 cells to the test chemicals for 24 and $48 \mathrm{~h}$ in the absence of NaI. Iodide uptake was determined at the end of the treatment. To minimize the potential effect of cytotoxicity on the iodide uptake, an MTT assay was performed to monitor the viability of FRTL-5 cells following exposure to triclosan, triclocarban, BDE-47, and BPA. No significant decrease in viability was observed in cells exposed to triclosan at $\leq 10 \mu \mathrm{M}$, triclocarban at $\leq 3 \mu \mathrm{M}$, BDE- 47 at $\leq 10 \mu \mathrm{M}$, or BPA at $\leq$ 
$30 \mu \mathrm{M}$ for up to $48 \mathrm{~h}$ (Fig. 4A). The highest tested concentrations in the long-term iodide uptake assay were selected in such a way to ensure that the cell viability was at least 70\% throughout the experiment. As shown in Fig. 4B, there was a significant decrease in iodide uptake in FRTL-5 cells exposed to triclosan, triclocarban, BDE-47, or BPA, with the decrease occurring at non-cytotoxic concentrations.

\section{Effects of triclosan, triclocarban, BDE-47, and BPA on the expression of genes involved in TH synthesis}

The transcriptional expression levels of three genes involved in TH synthesis (Slc5a5, Tpo, and $T g$ ) were examined in FRTL-5 cells exposed to the test chemicals for 6, 24, and $48 \mathrm{~h}$. No significant changes in the expression of any genes were observed in cells exposed to triclosan or triclocarban (Fig. 5A). The levels of Tpo were reduced in cells exposed to 30 $\mu \mathrm{M}$ of BDE-47 for $24 \mathrm{~h}$ or $48 \mathrm{~h}$. Exposure to BPA down-regulated the expression of Slc5a5 and Tpo only at the highest concentration of $100 \mu \mathrm{M}$, while the expression of $T g$ was up-regulated in a concentration-dependent manner (Fig. 5A). A shorter exposure (6 h) did not cause any changes in the expression in any of the genes.

The transcriptional expression of Slc5a5, Tpo, and $T g$ is regulated by several thyroid transcription factors, including Pax8, FoxE1, and Nkx2-1, which are critical for thyroid function (Kimura, 2011). The effect of the test chemicals on the expression of these transcription factors was examined. Triclosan, triclocarban, and BDE-47 did not significantly affect the expression levels of Pax8, Foxe1, or $N k x 2-1$ (Fig. 5B). In contrast, there was a concentration-dependent increase in the levels of Pax8 and Foxel in cells following exposure to BPA, with the increase being significant at the highest concentration of $100 \mu \mathrm{M}$.

\section{Effects of triclosan, triclocarban, BDE-47, and BPA on the activity of TPO}

TPO is a protein critical for TH synthesis by catalyzing the oxidation of iodide and the addition of iodide to the tyrosine residues of thyroglobulin (Taurog et al., 1996). A variety of compounds have been reported to target TPO and inhibit TH synthesis (Doerge and Chang, 
2002; Paul et al., 2014; Schmutzler et al., 2007a). Triclosan, triclocarban, BDE-47, and BPA were evaluated for their effects on the activity of TPO in isolated rat thyroid microsomes. Triclosan inhibited TPO activity in a concentration-dependent manner, with the $\mathrm{IC}_{50}$ value being $165.8 \mu \mathrm{M}$ (Fig. 6). Although triclocarban also displayed a concentration-dependent inhibitory effect on TPO activity, the potency was rather low with the $\mathrm{IC}_{50}$ value being $>300$ $\mu \mathrm{M}$. Neither BDE-47 nor BPA affected TPO activity (Fig. 6).

\section{$\underline{\text { Discussion }}$}

Triclosan, triclocarban, BDE-47, and BPA are well-known endocrine disruptors. Although previous studies have reported the alteration of $\mathrm{TH}$ metabolism and transport, their effects on TH synthesis remain poorly understood. In this study we examined both the short- and longterm effects on iodide uptake and demonstrated that all four chemicals inhibited NISmediated iodide uptake in FRTL-5 cells. NIS is a key transmembrane glycoprotein that mediates transport of iodide into thyroid follicular cells. Anions, including perchlorate and thiocyanate, are well-known competitive inhibitors of human NIS (Tonacchera et al., 2004), while hydrogen peroxide has been reported to inhibit NIS-mediated iodide uptake in a noncompetitive manner (Fukayama et al., 1991). In the current study, kinetics experiments showed that triclosan, triclocarban, BDE-47, and BPA were non-competitive inhibitors of NIS, with the $K_{i}$ value of triclosan being the smallest. One common mechanism of noncompetitive inhibition is the binding of the inhibitor to the enzyme at an allosteric site, which does not exclude the binding of native substrate at the active site but reduces the enzymatic activity. It is possible that the four chemicals tested here inhibited iodide uptake through a similar mechanism, but further studies are necessary regarding this matter because of the limited information of allosteric site of NIS.

NIS is regulated at both the transcriptional and post-translational levels, especially in relation to its subcellular localization (Kogai and Brent, 2012). Under physiological conditions, NIS is located at the basolateral membrane of the thyroid follicular cells, which is required for its functionality in mediating iodide uptake. Removal of TSH suppresses iodide uptake via both 
down-regulating the transcriptional expression of Slc $5 a 5$ and preventing NIS from translocating to plasma membrane (Riedel et al., 2001). The observations that exposure to triclosan, triclocarban, BDE-47, and BPA inhibited NIS-mediated iodide uptake (Fig. 4B), but did not influence the transcriptional expression levels of Slc5a5 (Fig. 5A) suggest that the four chemicals may affect the NIS at the post-translational level. Furthermore, when FRTL-5 cells were incubated with triclocarban, BDE-47, or BPA in the absence of NaI, inhibition of iodide uptake was observed at as low as $0.3,10$, and $10 \mu \mathrm{M}$, respectively (Fig. 4B). These concentrations were much lower than the $\mathrm{IC}_{50}$ values for iodide uptake (17.2, 41.5, and 91.7 $\mu \mathrm{M}$ ) when FRTL-5 cells were exposed to the test chemicals and NaI simultaneously (Fig. 1). These data suggest the possibility that the inhibition of iodide uptake by triclocarban, BDE47 , and BPA is mediated primarily through regulating NIS at the post-translational level. In contrast, triclosan exhibited inhibitory effect on the iodide uptake at comparable concentrations (6.6 versus $10 \mu \mathrm{M}$ ), in the presence or absence of NaI. Thus, triclosan may acts as an inhibitor of iodide uptake via both binding to NIS and regulating NIS at the posttranslational level. It is also likely that triclosan binds to NIS at an allosteric site, without effecting the post-translational regulation of NIS.

The expression levels of Slc5a5, Tpo, Tg, Pax8, Foxe1, and Nkx2-1 were not affected by triclosan, triclocarban, or BDE-47, the only exception being the effect of $30 \mu \mathrm{M}$ BDE-47 on Tpo. However, exposure to BPA induced alterations in the levels of these genes. There was an increased trend in the levels of $T g$, Pax8, and Foxel in cells following BPA exposure, although the changes with regard to Pax8 and Foxel were only significant at $100 \mu \mathrm{M}$ BPA. Therefore, it is possible that the up-regulation of $T g$ by BPA was mediated through thyroid transcription factors Pax8 and FoxE1. The TPO inhibitor propylthiouracil has been shown to increase the expression level of Slc5a5 and iodide uptake in FRTL-5 cells, whereas another TPO inhibitor methimazole did not exhibit a similar effect (Sue et al., 2012). In addition, there were no significant changes in the levels of Tpo, Tg, Nkx2-1, Foxe1, and Pax8 following exposure to either chemical. Soy extracts have been reported to inhibit iodide uptake, but increase the protein level of non-glycosylated NIS and a $40 \mathrm{kDa}$ Tg fragment in FRTL-5 cells (Tran et al., 2013). Previous reports and the data presented in this study 
Although triclosan and triclocarban inhibited the TPO activity in a concentration-dependent manner, TPO seemed not a primary target of these two chemicals, because the $\mathrm{IC}_{50}$ values for TPO activity inhibition were much higher than those for iodide uptake. A low inhibitory potency of triclosan on TPO activity has also been reported in the same assay in a high-throughput screening mode, with the $\mathrm{IC}_{50}$ value being $184 \mu \mathrm{M}$ (Paul et al., 2014), which is comparable to the value $(166 \mu \mathrm{M})$ shown in the current study. The performance of four known TPO inhibitors, including [methimazole, propylthiouracil, 2mercaptobenzothiazole (MBT), and ethylene thiourea (ETU)] was also tested in the current study, with their $\mathrm{IC}_{50}$ values being 3.1, 27.9, 1.2, and > $300 \mu \mathrm{M}$, respectively (Suppl. Fig. 1). The potency of these chemicals was consistent with previous reports using conventional assays (Freyberger and Ahr, 2006; Schmutzler et al., 2007b; Tietge et al., 2013; Vickers et al., 2012), but lower than that reported by Paul et al. using a highthroughput screening mode, which could due to the higher sensitivity of the assay performed in a high-throughput screening mode (Paul et al., 2014).

Due to the extensive use of triclosan, the general population is exposed to triclosan through the ingestion or dermal contact with daily hygiene products and the consumption of food and drinking water contaminated with triclosan. The blood levels of total triclosan in humans following use of either mouth rinses or dentifrices vary among different individuals and can be as high as $1.4 \mu \mathrm{M}$ (DeSalva et al., 1989; Sandborgh-Englund et al., 2006). We have previously found that mice dermally treated with $100 \mathrm{mg}$ triclosan/kg body weight have plasma levels of triclosan and its metabolites of approximately $150 \mu \mathrm{M}$ (Fang et al., 2014), and the topical application of similar level of triclosan resulted in a decrease in the serum T4 levels in mice (Fang et al., 2015). In the present study, inhibition of iodide uptake by triclosan was observed under concentrations that were comparable to the plasma levels in mice and approaching human relevant levels. Nonetheless, triclosan is 
extensively metabolized in mice following dermal application, and the extent of its metabolites varies among tissues and body fluids, with the parent compound being only $1 \%$ in the plasma (Fang et al., 2014). Since we did not examine the effects of triclosan metabolites on the iodide uptake, caution should be exercised in extrapolating the findings in this in vitro study to potential effects in humans. In addition, the test models used in the current study were a rat-derived cell line and microsomes isolated from rat thyroid, and there may be species difference in both the toxicokinetics of triclosan and the pharmacokinetics of thyroid functions between humans and rats should be considered.

Triclosan, BDE-47, and BPA have been demonstrated to disrupt TH homeostasis in rodents, and epidemiological studies also suggest potential adverse effects in humans (Koeppe $\mathrm{et} \mathrm{al}$., 2013; Stapleton et al., 2011; Wang et al., 2013). Although there is a lack of rodent studies investigating the influence of triclocarban on the thyroid system, triclocarban has been reported to alter the expression levels of TH responsive genes in vitro. Several studies have reported that serum concentrations of triclocarban and BPA in humans are in the $\mathrm{nM}$ range for triclocarban (Ye et al., 2011) and the pM range for BPA (Teeguarden et al., 2013); PBDEs are in the range of ng/g lipid (Sjödin et al., 2008). The lowest observed concentration of triclocarban that inhibited iodide uptake $(300 \mathrm{nM})$ in the present study was considered to be relevant to human exposure levels, whereas BPA and BDE-47 exhibited inhibitory effects on iodide uptake only at $10 \mu \mathrm{M}$, concentrations much higher than human blood levels. Therefore, although the concentrations of BPA and BDE-47 in human thyroid are currently unknown, the inhibition of iodide uptake by BPA and BDE-47 seems not to be a primary mechanism underlying their disturbing effects on $\mathrm{TH}$ homeostasis.

In conclusion, as summarized in Table 1, triclosan, triclocarban, BDE-47, and BPA acted as non-competitive inhibitors of NIS and inhibited NIS-mediated iodide uptake in FRTL-5 cells. Transcriptional expression levels of TH synthesis-related genes, including Slc5a5, Tpo, Tg, Pax8, Foxe1, and Nkx2-1, were not significant changed in cells following exposure to triclosan, triclocarban, or BDE-47 (with the exception of Tpo being affected by BDE-47), whereas BPA induced alterations in the levels of each of these genes. Compared to iodide 
uptake, TPO seemed not a primary target of the test chemicals.

2

3

4

5 


\section{$\underline{\text { Acknowledgements }}$}

Yuanfeng Wu was supported by an appointment to the Postgraduate Research Program in the Division of Biochemical Toxicology at the National Center for Toxicological Research administered by Oak Ridge Institute for Science Education through an interagency agreement between the U.S. Department of Energy and the U.S. FDA.

\section{Conflict of interest statement}

The authors declare that there are no conflicts of interest.

\section{References}

Boas, M., Feldt-Rasmussen, U., Skakkebaek, N. E., and Main, K. M. (2006). Environmental chemicals and thyroid function. Eur. J. Endocrinol. 154, 599-611.

Crofton, K. M., Paul, K. B., DeVito, M. J., and Hedge, J. M. (2007). Short-term in vivo exposure to the water contaminant triclosan: evidence for disruption of thyroxine. Environ. Toxicol. Pharmacol. 24, 194-197.

Delclos, K. B., Camacho, L., Lewis, S. M., Vanlandingham, M. M., Latendresse, J. R., Olson, G. R., Davis, K. J., Patton, R. E., Gamboa da Costa, G., Woodling, K. A., Bryant, M. S., Chidambaram, M., Trbojevich, R., Juliar, B. E., Felton, R. P., and Thorn, B. T. (2014). Toxicity evaluation of bisphenol A administered by gavage to Sprague Dawley rats from gestation day 6 through postnatal day 90. Toxicol. Sci. 139, 174-197. DeSalva, S. J., Kong, B. M., and Lin, Y. J. (1989). Triclosan: a safety profile. Am. J. Dent. 2 Spec No, 185196.

Doerge, D. R., and Chang, H. C. (2002). Inactivation of thyroid peroxidase by soy isoflavones, in vitro and in vivo. J Chromatogr B 777, 269-279.

Ellis-Hutchings, R. G., Cherr, G. N., Hanna, L. A., and Keen, C. L. (2006). Polybrominated diphenyl ether (PBDE)-induced alterations in vitamin A and thyroid hormone concentrations in the rat during lactation and early postnatal development. Toxicol. Appl. Pharmacol. 215, 135-145.

Fang, J.-L., Stingley, R. L., Beland, F. A., Harrouk, W., Lumpkins, D. L., and Howard, P. (2010). Occurrence, efficacy, metabolism, and toxicity of triclosan. J. Environ. Sci. Health C Environ. Carcinog. Ecotoxicol. Rev. 28, 147-171.

Fang, J.-L., Vanlandingham, M., Gamboa da Costa, G., and Beland, F. A. (2014). Absorption and metabolism of triclosan after application to the skin of B6C3F1 mice. Environ. Toxicol. doi: 10.1002/tox.22074. 
Fang, J.-L., Vanlandingham, M. M., Juliar, B. E., Olson, G. R., Patton, R. E., and Beland, F. A. (2015). Doseresponse assessment of the dermal toxicity of triclosan in B6C3F1 mice. Toxicol. Res. 4, 867-877. Freyberger, A., and Ahr, H. J. (2006). Studies on the goitrogenic mechanism of action of N,N,N',N'tetramethylthiourea. Toxicology 217, 169-175.

Fukayama, H., Murakami, S., Nasu, M., and Sugawara, M. (1991). Hydrogen peroxide inhibits iodide uptake and iodine organification in cultured porcine thyroid follicles. Thyroid 1, 267-271.

Hallgren, S., Sinjari, T., Hakansson, H., and Darnerud, P. O. (2001). Effects of polybrominated diphenyl ethers (PBDEs) and polychlorinated biphenyls (PCBs) on thyroid hormone and vitamin A levels in rats and mice. Arch. Toxicol. 75, 200-208.

Hinther, A., Bromba, C. M., Wulff, J. E., and Helbing, C. C. (2011). Effects of triclocarban, triclosan, and methyl triclosan on thyroid hormone action and stress in frog and mammalian culture systems. Environ. Sci. Technol. 45, 5395-5402.

Hites, R. A. (2004). Polybrominated diphenyl ethers in the environment and in people: a meta-analysis of concentrations. Environ. Sci. Technol. 38, 945-956.

Kimura, S. (2011). Thyroid-specific transcription factors and their roles in thyroid cancer. J. Thyroid Res. 2011, 710213.

Koeppe, E. S., Ferguson, K. K., Colacino, J. A., and Meeker, J. D. (2013). Relationship between urinary triclosan and paraben concentrations and serum thyroid measures in NHANES 2007-2008. Sci. Total Environ. 445-446, 299-305.

Kogai, T., and Brent, G. A. (2012). The sodium iodide symporter (NIS): regulation and approaches to targeting for cancer therapeutics. Pharmacol. Ther. 135, 355-370.

Kogai, T., Schultz, J. J., Johnson, L. S., Huang, M., and Brent, G. A. (2000). Retinoic acid induces sodium/iodide symporter gene expression and radioiodide uptake in the MCF-7 breast cancer cell line. Proc. Natl. Acad. Sci. U. S. A. 97, 8519-8524.

Kosugi, S., Sasaki, N., Hai, N., Sugawa, H., Aoki, N., Shigemasa, C., Mori, T., and Yoshida, A. (1996). Establishment and characterization of a Chinese hamster ovary cell line, $\mathrm{CHO}-4 \mathrm{~J}$, stably expressing a number of $\mathrm{Na}^{+} / \mathrm{I}^{-}$symporters. Biochem. Biophys. Res. Commun. 227, 94-101.

Marchesini, G. R., Meimaridou, A., Haasnoot, W., Meulenberg, E., Albertus, F., Mizuguchi, M., Takeuchi, M., Irth, H., and Murk, A. J. (2008). Biosensor discovery of thyroxine transport disrupting chemicals. Toxicol. Appl. Pharmacol. 232, 150-160.

Marlatt, V. L., Veldhoen, N., Lo, B. P., Bakker, D., Rehaume, V., Vallee, K., Haberl, M., Shang, D., van Aggelen, G. C., Skirrow, R. C., Elphick, J. R., and Helbing, C. C. (2013). Triclosan exposure alters postembryonic development in a Pacific tree frog (Pseudacris regilla) Amphibian Metamorphosis Assay (TREEMA). Aquat. Toxicol. 126, 85-94.

Meerts, I. A. T. M., van Zanden, J. J., Luijks, E. A. C., van Leeuwen-Bol, I., Marsh, G., Jakobsson, E., Bergman, A., and Brouwer, A. (2000). Potent competitive interactions of some brominated flame retardants and related compounds with human transthyretin in vitro. Toxicol. Sci. 56, 95-104.

Moriyama, K., Tagami, T., Akamizu, T., Usui, T., Saijo, M., Kanamoto, N., Hataya, Y., Shimatsu, A., Kuzuya, H., and Nakao, K. (2002). Thyroid hormone action is disrupted by bisphenol A as an antagonist. J. Clin. Endocrinol. Metab. 87, 5185-5190.

Mullur, R., Liu, Y.-Y., and Brent, G. A. (2014). Thyroid hormone regulation of metabolism. Physiol. Rev. 94, 355-382.

Patrick, L. (2009). Thyroid disruption: mechanism and clinical implications in human health. Altern. Med. Rev. 14, 326-346. 
Paul, K. B., Hedge, J. M., Bansal, R., Zoeller, R. T., Peter, R., DeVito, M. J., and Crofton, K. M. (2012). Developmental triclosan exposure decreases maternal, fetal, and early neonatal thyroxine: a dynamic and kinetic evaluation of a putative mode-of-action. Toxicology 300, 31-45.

Paul, K. B., Hedge, J. M., DeVito, M. J., and Crofton, K. M. (2010). Short-term exposure to triclosan decreases thyroxine in vivo via upregulation of hepatic catabolism in young Long-Evans rats. Toxicol. Sci. 113, 367-379.

Paul, K. B., Hedge, J. M., Rotroff, D. M., Hornung, M. W., Crofton, K. M., and Simmons, S. O. (2014). Development of a thyroperoxidase inhibition assay for high-throughput screening. Chem. Res. Toxicol. 27 , 387-399.

Pinto, P. I. S., Guerreiro, E. M., and Power, D. M. (2013). Triclosan interferes with the thyroid axis in the zebrafish (Danio rerio). Toxicol. Res. 2, 60-69.

Richardson, V. M., Staskal, D. F., Ross, D. G., Diliberto, J. J., DeVito, M. J., and Birnbaum, L. S. (2008). Possible mechanisms of thyroid hormone disruption in mice by BDE 47, a major polybrominated diphenyl ether congener. Toxicol. Appl. Pharmacol. 226, 244-250.

Riedel, C., Levy, O., and Carrasco, N. (2001). Post-transcriptional regulation of the sodium/iodide symporter by thyrotropin. J. Biol. Chem. 276, 21458-21463.

Rubin, B. S. (2011). Bisphenol A: an endocrine disruptor with widespread exposure and multiple effects. $J$. Steroid Biochem. Mol. Biol. 127, 27-34.

Sandborgh-Englund, G., Adolfsson-Erici, M., Odham, G., and Ekstrand, J. (2006). Pharmacokinetics of triclosan following oral ingestion in humans. J. Toxicol. Environ. Health A 69, 1861-1873.

Schmutzler, C., Bacinski, A., Gotthardt, I., Huhne, K., Ambrugger, P., Klammer, H., Schlecht, C., Hoang-Vu, C., Gruters, A., Wuttke, W., Jarry, H., and Kohrle, J. (2007a). The ultraviolet filter benzophenone 2 interferes with the thyroid hormone axis in rats and is a potent in vitro inhibitor of human recombinant thyroid peroxidase. Endocrinology 148, 2835-2844.

Schmutzler, C., Bacinski, A., Gotthardt, I., Huhne, K., Ambrugger, P., Klammer, H., Schlecht, C., Hoang-Vu, C., Gruters, A., Wuttke, W., Jarry, H., and Kohrle, J. (2007b). The ultraviolet filter benzophenone 2 interferes with the thyroid hormone axis in rats and is a potent in vitro inhibitor of human recombinant thyroid peroxidase. Endocrinology 148, 2835-2844.

Sheng, Z.-G., Tang, Y., Liu, Y.-X., Yuan, Y., Zhao, B.-Q., Chao, X.-J., and Zhu, B.-Z. (2012). Low concentrations of bisphenol a suppress thyroid hormone receptor transcription through a nongenomic mechanism. Toxicol. Appl. Pharmacol. 259, 133-142.

Sjödin, A., Wong, L.-Y., Jones, R. S., Park, A., Zhang, Y., Hodge, C., DiPietro, E., McClure, C., Turner, W., Needham, L. L., and Patterson, D. G., Jr. (2008). Serum concentrations of polybrominated diphenyl ethers (PBDEs) and polybrominated biphenyl (PBB) in the United States population: 2003-2004. Environ. Sci. Technol. 42, 1377-1384.

Stapleton, H. M., Eagle, S., Anthopolos, R., Wolkin, A., and Miranda, M. L. (2011). Associations between polybrominated diphenyl ether (PBDE) flame retardants, phenolic metabolites, and thyroid hormones during pregnancy. Environ. Health Perspect. 119, 1454-1459.

Sue, M., Akama, T., Kawashima, A., Nakamura, H., Hara, T., Tanigawa, K., Wu, H., Yoshihara, A., Ishido, Y., Hiroi, N., Yoshino, G., Kohn, L. D., Ishii, N., and Suzuki, K. (2012). Propylthiouracil increases sodium/iodide symporter gene expression and iodide uptake in rat thyroid cells in the absence of TSH. Thyroid 22, 844-852.

Szabo, D. T., Richardson, V. M., Ross, D. G., Diliberto, J. J., Kodavanti, P. R. S., and Birnbaum, L. S. (2009). Effects of perinatal PBDE exposure on hepatic phase I, phase II, phase III, and deiodinase 1 gene expression 
involved in thyroid hormone metabolism in male rat pups. Toxicol. Sci. 107, 27-39.

Taurog, A., Dorris, M. L., and Doerge, D. R. (1996). Mechanism of simultaneous iodination and coupling catalyzed by thyroid peroxidase. Arch. Biochem. Biophys. 330, 24-32.

Teeguarden, J., Hanson-Drury, S., Fisher, J. W., and Doerge, D. R. (2013). Are typical human serum BPA concentrations measurable and sufficient to be estrogenic in the general population? Food Chem. Toxicol. 62, 949-963.

Tietge, J. E., Degitz, S. J., Haselman, J. T., Butterworth, B. C., Korte, J. J., Kosian, P. A., Lindberg-Livingston, A. J., Burgess, E. M., Blackshear, P. E., and Hornung, M. W. (2013). Inhibition of the thyroid hormone pathway in Xenopus laevis by 2-mercaptobenzothiazole. Aquat. Toxicol. 126, 128-136.

Tonacchera, M., Pinchera, A., Dimida, A., Ferrarini, E., Agretti, P., Vitti, P., Santini, F., Crump, K., and Gibbs, J. (2004). Relative potencies and additivity of perchlorate, thiocyanate, nitrate, and iodide on the inhibition of radioactive iodide uptake by the human sodium iodide symporter. Thyroid 14, 1012-1019.

Tran, L., Hammuda, M., Wood, C., and Xiao, C. W. (2013). Soy extracts suppressed iodine uptake and stimulated the production of autoimmunogen in rat thyrocytes. Exp. Biol. Med. (Maywood) 238, 623-630. Vickers, A. E., Heale, J., Sinclair, J. R., Morris, S., Rowe, J. M., and Fisher, R. L. (2012). Thyroid organotypic rat and human cultures used to investigate drug effects on thyroid function, hormone synthesis and release pathways. Toxicol. Appl. Pharmacol. 260, 81-88.

Vitale, G., Salvioli, S., and Franceschi, C. (2013). Oxidative stress and the ageing endocrine system. Nat. Rev. Endocrinol. 9, 228-240.

Waltz, F., Pillette, L., and Ambroise, Y. (2010). A nonradioactive iodide uptake assay for sodium iodide symporter function. Anal. Biochem. 396, 91-95.

Wang, T. G., Lu, J. L., Xu, M., Xu, Y., Li, M., Liu, Y., Tian, X. G., Chen, Y. H., Dai, M., Wang, W. Q., Lai, S. H., Bi, Y. F., and Ning, G. (2013). Urinary Bisphenol A Concentration and Thyroid Function in Chinese Adults. Epidemiology 24, 295-302.

Witorsch, R. J., and Thomas, J. A. (2010). Personal care products and endocrine disruption: a critical review of the literature. Crit. Rev. Toxicol. 40 Suppl 3, 1-30.

Wu, S.-y., Green, W. L., Huang, W.-s., Hays, M. T., and Chopra, I. J. (2005). Alternate pathways of thyroid hormone metabolism. Thyroid 15, 943-958.

Wu, Y., Beland, F. A., Chen, S., and Fang, J.-L. (2015). Extracellular signal-regulated kinases 1/2 and Akt contribute to triclosan-stimulated proliferation of JB6 Cl 41-5a cells. Arch. Toxicol. 89, 1297-1311.

Xu, X.-h., Zhang, J., Wang, Y.-m., Ye, Y.-p., and Luo, Q.-q. (2010). Perinatal exposure to bisphenol-A impairs learning-memory by concomitant down-regulation of $N$-methyl- $D$-aspartate receptors of hippocampus in male offspring mice. Horm. Behav. 58, 326-333.

Xu, X., Liu, Y., Sadamatsu, M., Tsutsumi, S., Akaike, M., Ushijima, H., and Kato, N. (2007). Perinatal bisphenol A affects the behavior and SRC-1 expression of male pups but does not influence on the thyroid hormone receptors and its responsive gene. Neurosci. Res. 58, 149-155.

Ye, X., Zhou, X., Furr, J., Ahn, K. C., Hammock, B. D., Gray, E. L., and Calafat, A. M. (2011). Biomarkers of exposure to triclocarban in urine and serum. Toxicology 286, 69-74.

Zhou, T., Ross, D. G., DeVito, M. J., and Crofton, K. M. (2001). Effects of short-term in vivo exposure to polybrominated diphenyl ethers on thyroid hormones and hepatic enzyme activities in weanling rats. Toxicol. Sci. 61, 76-82.

Zoeller, R. T., Bansal, R., and Parris, C. (2005). Bisphenol-A, an environmental contaminant that acts as a thyroid hormone receptor antagonist in vitro, increases serum thyroxine, and alters RC3/neurogranin expression in the developing rat brain. Endocrinology 146, 607-612. 


\section{Figure legends}

Fig. 1 Short-term effects of triclosan, triclocarban, BDE-47, and BPA on the iodide uptake in FRTL-5 cells. Iodide uptake curves of FRTL-5 cells co-incubated with various concentrations of the indicated chemical and $10 \mu \mathrm{M} \mathrm{NaI}$ for $1 \mathrm{~h}$. The results shown are the mean and standard deviation of three independent experiments.

Fig. 2 Validation of the non-radioactive iodide uptake assay in kinetic studies. (A) The standard curve of iodide content. A series of standard solutions $(100 \mu \mathrm{l})$ with known concentrations of $\mathrm{NaI}(0,100,200,300,400,500,600,700,1000$, or $2000 \mathrm{nM})$ were added to each well of a 96-well plate. This is equivalent to iodide content of $0-200$ pmol per well. The non-radioactive iodide uptake assay was carried out as described in Materials and Methods. The logarithm of $\mathrm{A}_{420}$ was plotted against the iodide content, and linear regression was performed using GraphPad Prism 6.0 to obtain the standard curve. (B) Time-dependent iodide uptake in FRTL-5 cells incubated with $10 \mu \mathrm{M} \mathrm{NaI}$ for 2, 5, 10, 20, 30, 60 or 120 min. (C) Substrate concentration-dependent initial velocity of iodide uptake in FRTL-5 cells incubated with $5,10,20,40,80,160$, or $320 \mu \mathrm{M}$ NaI for 5 min. (D) Lineweaver-Burk plot of data shown in (C). Linear regression was performed by GraphPad Prism 6. The $K_{m}$ value was determined as the reciprocal of the $\mathrm{X}$-intercept of the linear regression line. Values shown in the parenthesis are the $95 \%$ confidence intervals. The results shown are the mean and standard deviation of three independent experiments.

\section{Fig. 3 Kinetics of inhibition of iodide uptake by triclosan, triclocarban, BDE-47, and} BPA. (A - D) Lineweaver-Burk plots showing the initial velocity of iodide uptake in FRTL5 cells co-incubated with various concentrations of the indicated chemical and $\mathrm{NaI}(5,10,20$, or $40 \mu \mathrm{M}$ ) for $5 \mathrm{~min}$. Linear regression was performed by GraphPad Prism 6. (E - H) Plots of slopes of linear regression lines shown in A - D against the concentrations of the test chemicals. Linear regression was performed by GraphPad Prism 6. The inhibition constant $\left(K_{i}\right)$ values were determined as the $\mathrm{X}$-intercepts of the linear regression lines shown in $\mathrm{E}-\mathrm{H}$. The results shown are the mean and standard deviation of three independent experiments. 


\section{Fig. 4 Long-term effects of triclosan, triclocarban, BDE-47, and BPA on the iodide} uptake in FRTL-5 cells. (A) Representative cell growth curves of FRTL-5 cells treated with triclosan, triclocarban, BDE-47, or BPA $(0.03-300 \mu \mathrm{M})$ for 24 or $48 \mathrm{~h}$. The results shown are the mean and standard deviation of three independent experiments. (B) Iodide uptake of FRTL-5 cells that were exposed to various concentrations of triclosan, triclocarban, BDE-47, or BPA for 24 or $48 \mathrm{~h}$. At the end of the treatment, cells were washed with iodide uptake buffer and then incubated with $10 \mu \mathrm{M} \mathrm{NaI}$ for $1 \mathrm{~h}$. MTT assays were performed in parallel plates. Iodide uptake was normalized to the MTT assay data, and further normalized to the control. The results shown are the mean and standard deviation of three independent experiments. ${ }^{*}$, significantly $(p<0.05)$ different from the control group.

\section{Fig. 5 Effects of triclosan, triclocarban, BDE-47, and BPA on the expression of genes} involved in TH synthesis. FRTL-5 cells were exposed to the indicated concentration of triclosan, triclocarban, BDE-47, or BPA for 6, 24 or $48 \mathrm{~h}$. Transcriptional expression levels of Slc5a5, Tpo, Tg, Pax8, Foxe1, and Nkx2-1 were determined using quantitative real-time PCR. The results shown are the mean and standard deviation of three independent experiments. ${ }^{*}$, significantly $(p<0.05)$ different from the control group.

\section{Fig. 6 Effects of triclosan, triclocarban, BDE-47, and BPA on the activity of TPO.}

Curves of activity of TPO in rat thyroid microsomes incubated with various concentrations of triclosan, triclocarban, BDE-47, or BPA. The results shown are the mean and standard deviation of three independent experiments. The $\mathrm{IC}_{50}$ values were obtained from the TPO activity curves using GraphPad Prism 6.0. 
Table 1. Summary of the effects of triclosan, triclocarban, BDE-47, and BPA on iodide uptake, the expression levels of genes involved in TH synthesis in FRTL-5 cells, and the activity of TPO in rat thyroid microsomes.

\begin{tabular}{|c|c|c|c|c|c|c|}
\hline & & & Triclosan & Triclocarban & BDE-47 & BPA \\
\hline \multirow[t]{3}{*}{ Iodide uptake } & \multirow[t]{2}{*}{$\begin{array}{l}\text { Short-term } \\
\text { effects }\end{array}$} & $\begin{array}{l}\text { Inhibition } \\
\text { type }\end{array}$ & $\begin{array}{c}\text { Non- } \\
\text { competitive }\end{array}$ & $\begin{array}{c}\text { Non- } \\
\text { competitive }\end{array}$ & $\begin{array}{c}\text { Non- } \\
\text { competitive }\end{array}$ & $\begin{array}{c}\text { Non- } \\
\text { competitive }\end{array}$ \\
\hline & & $K_{i}(\mu \mathrm{M})$ & 21.3 & 69.0 & 77.8 & 112.3 \\
\hline & \multicolumn{2}{|c|}{ Long-term effects } & $\begin{array}{c}\text { Decrease at } \\
\geq 10 \mu \mathrm{M}\end{array}$ & $\begin{array}{c}\text { Decrease at } \\
\geq 0.3 \mu \mathrm{M}\end{array}$ & $\begin{array}{c}\text { Decrease at } \\
\geq 10 \mu \mathrm{M}\end{array}$ & $\begin{array}{c}\text { Decrease at } \\
\geq 10 \mu \mathrm{M}\end{array}$ \\
\hline \multirow{6}{*}{$\begin{array}{l}\text { mRNA } \\
\text { expression of } \\
\text { TH synthesis } \\
\text { related genes }\end{array}$} & \multicolumn{2}{|l|}{ Slc $5 a 5$} & No effect & No effect & No effect & $\begin{array}{c}\text { Decrease at } \\
100 \mu \mathrm{M}\end{array}$ \\
\hline & \multicolumn{2}{|l|}{ Тро } & No effect & No effect & $\begin{array}{c}\text { Decrease at } \\
100 \mu \mathrm{M}\end{array}$ & $\begin{array}{c}\text { Decrease at } \\
100 \mu \mathrm{M}\end{array}$ \\
\hline & \multicolumn{2}{|l|}{$T g$} & No effect & No effect & No effect & $\begin{array}{l}\text { Increase at } \\
\geq 30 \mu \mathrm{M}\end{array}$ \\
\hline & \multicolumn{2}{|l|}{$\operatorname{Pax} 8$} & No effect & No effect & No effect & $\begin{array}{c}\text { Increase at } \\
100 \mu \mathrm{M}\end{array}$ \\
\hline & \multicolumn{2}{|l|}{ Foxe1 } & No effect & No effect & No effect & $\begin{array}{c}\text { Increase at } \\
100 \mu \mathrm{M}\end{array}$ \\
\hline & \multicolumn{2}{|l|}{$N k x 2-1$} & No effect & No effect & No effect & No effect \\
\hline TPO activity & \multicolumn{2}{|l|}{$\mathrm{IC}_{50}(\mu \mathrm{M})$} & 165.8 & $>300$ & $>1000$ & $>1000$ \\
\hline
\end{tabular}



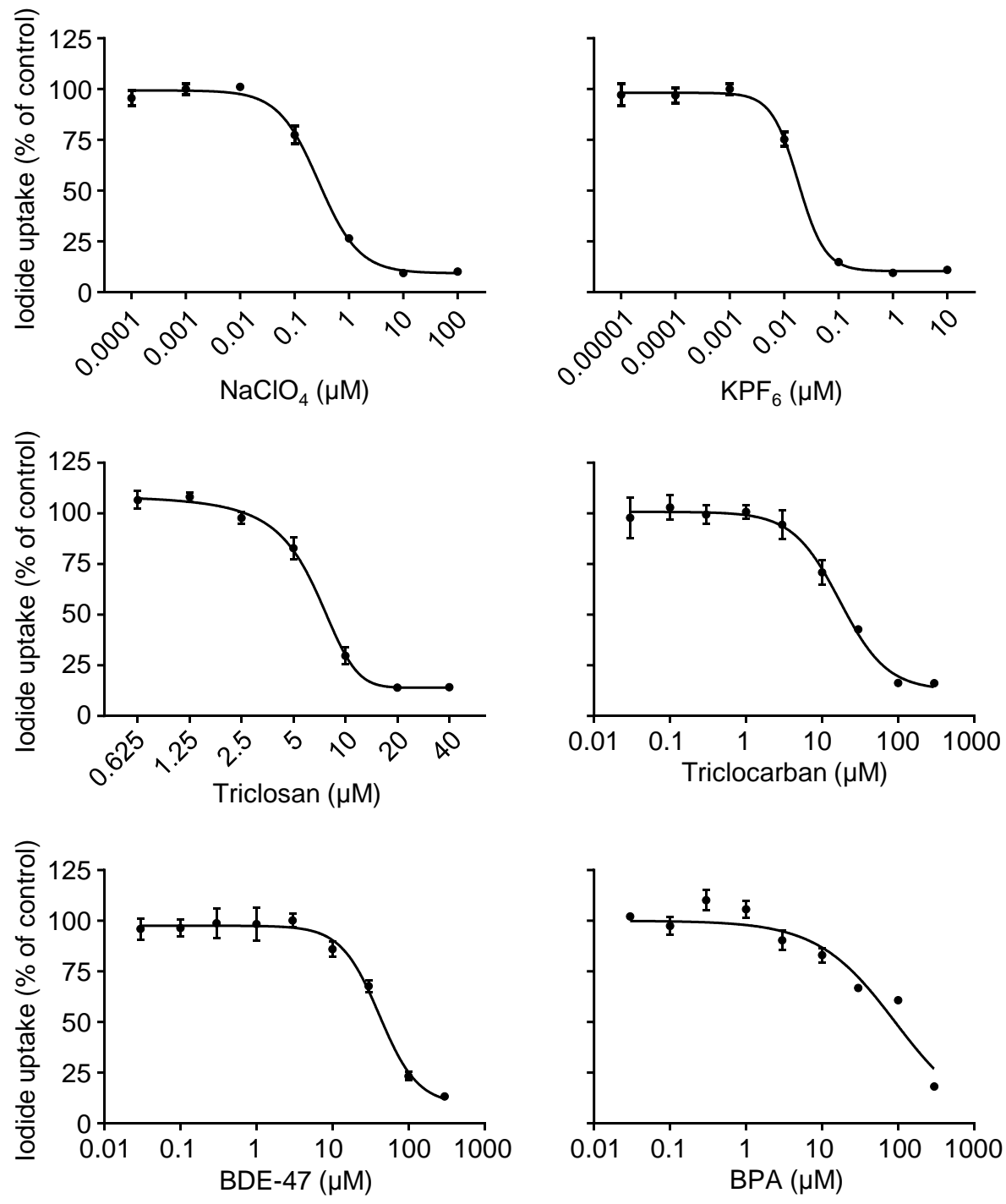
Fig. 2
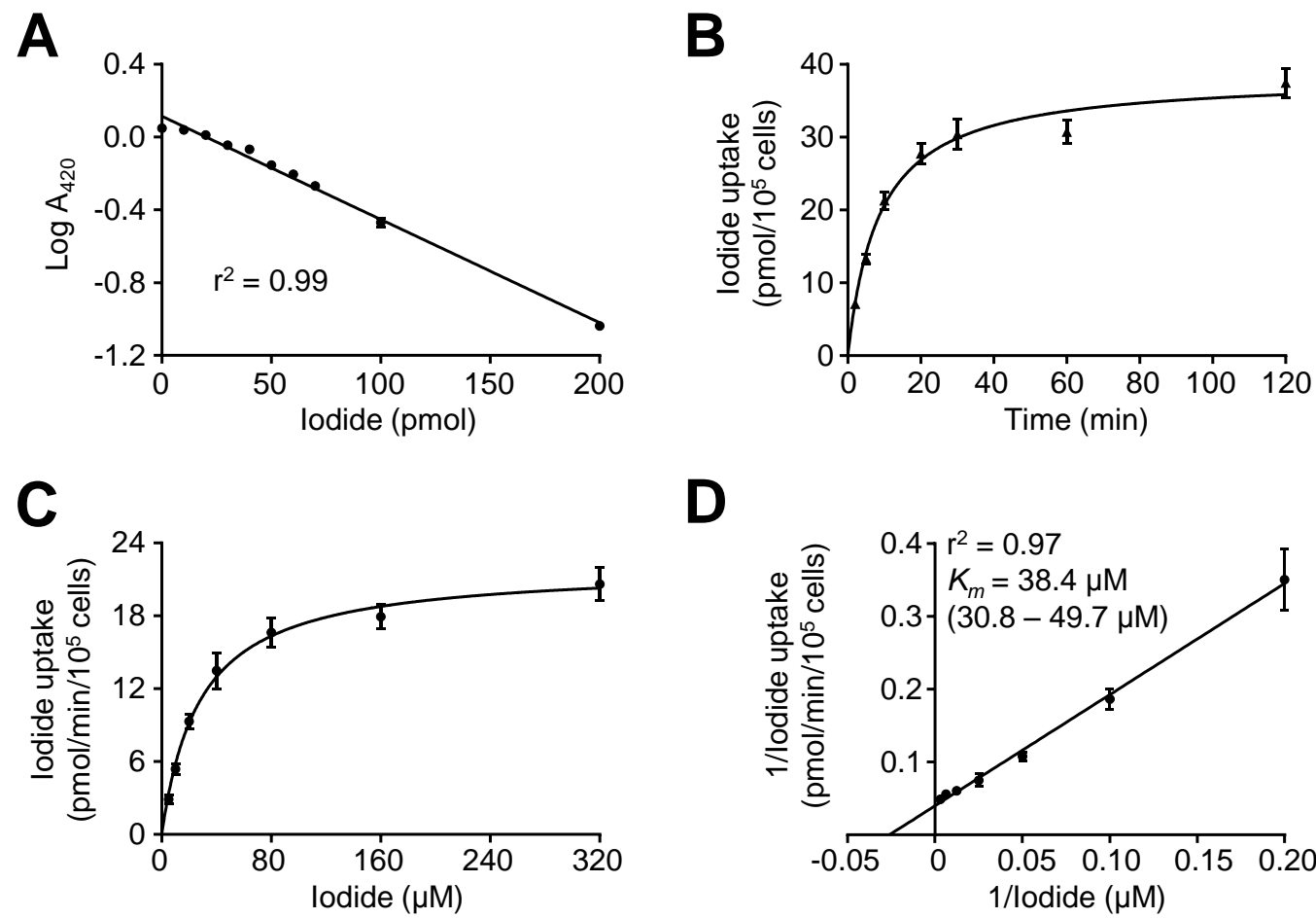

D

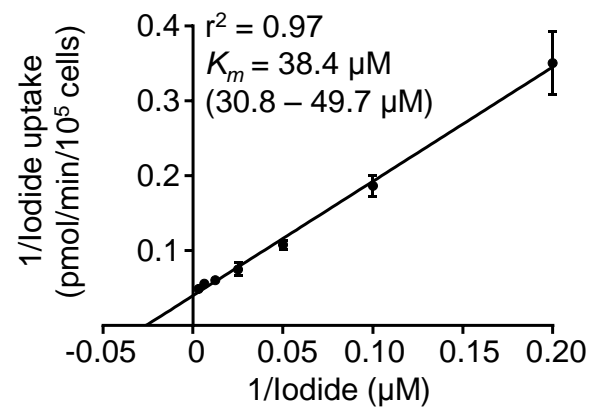


Fig. 3

A

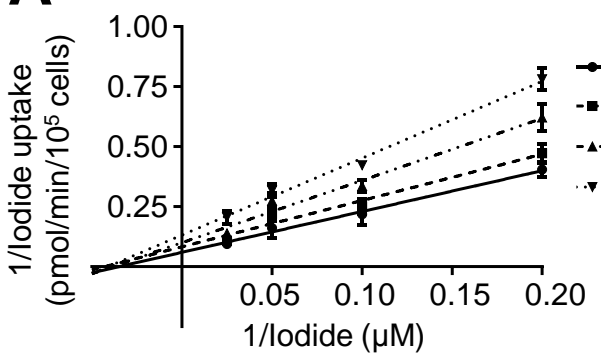

B

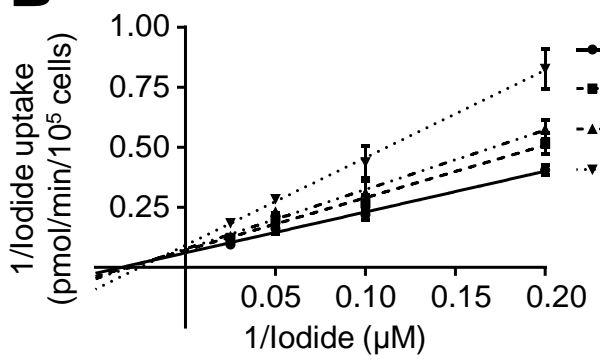

C

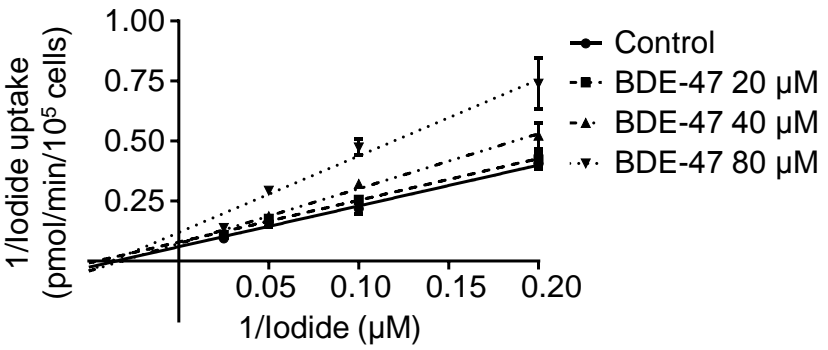

D

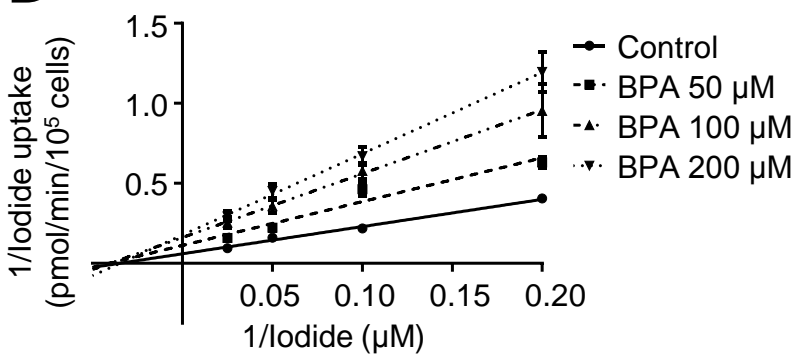

E
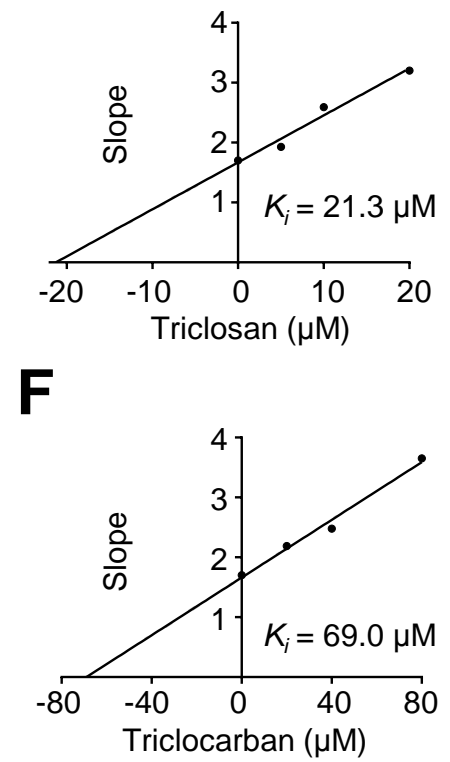

G

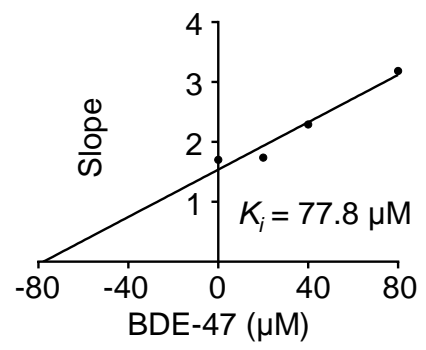

H

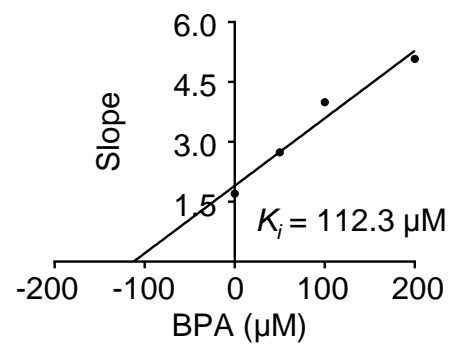


Fig. 4

A
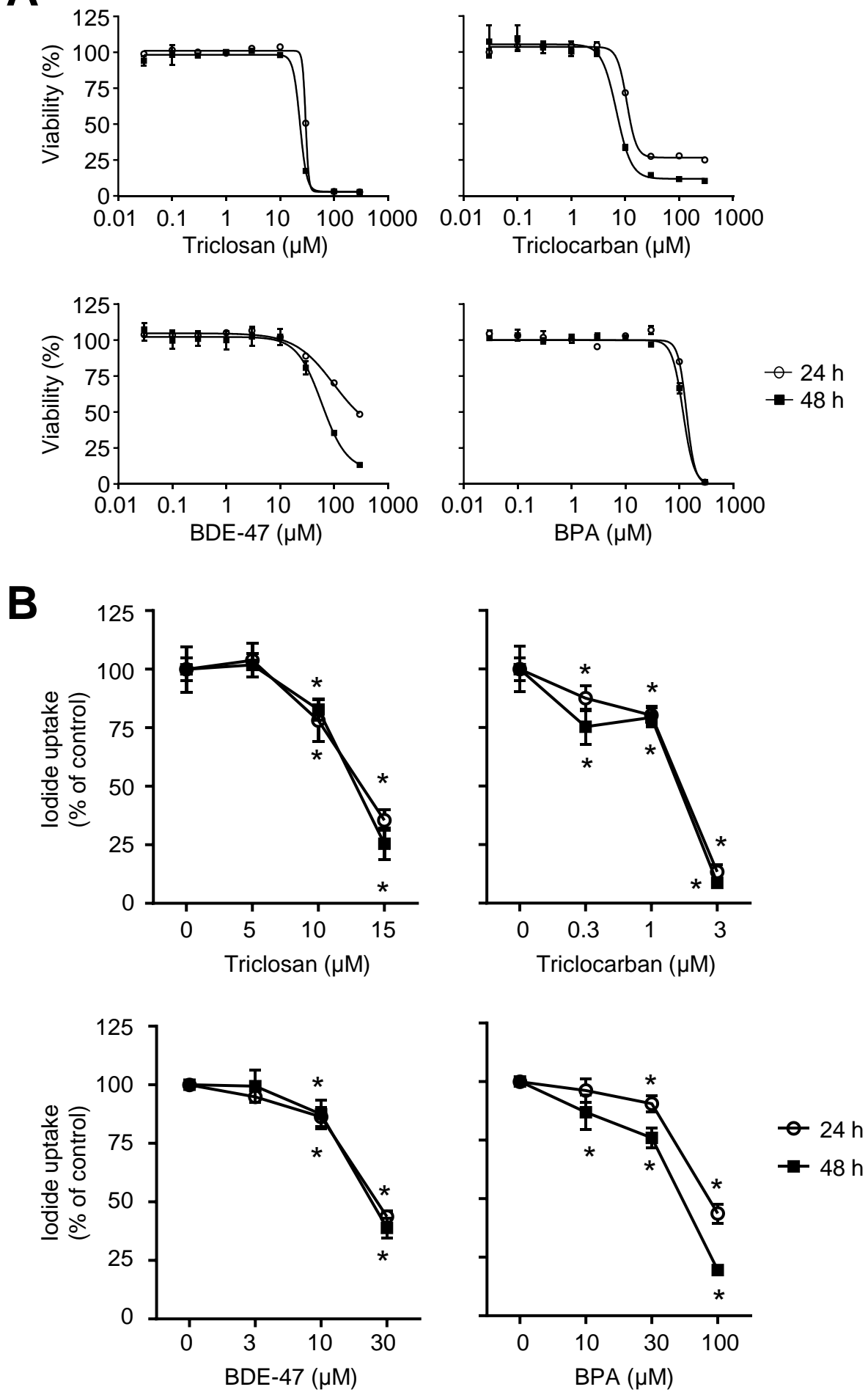
Fig. 5

A
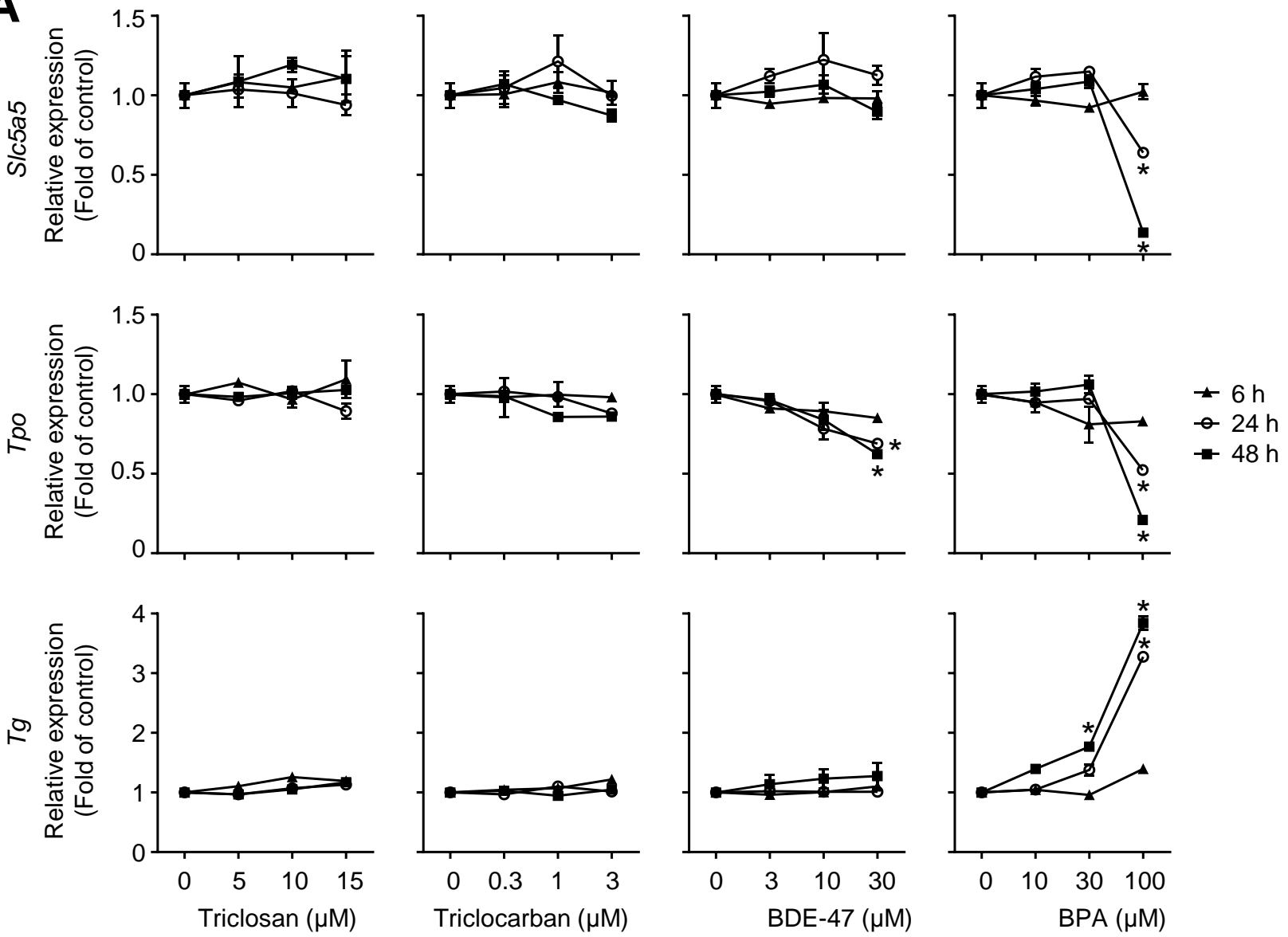
Fig. 5

B
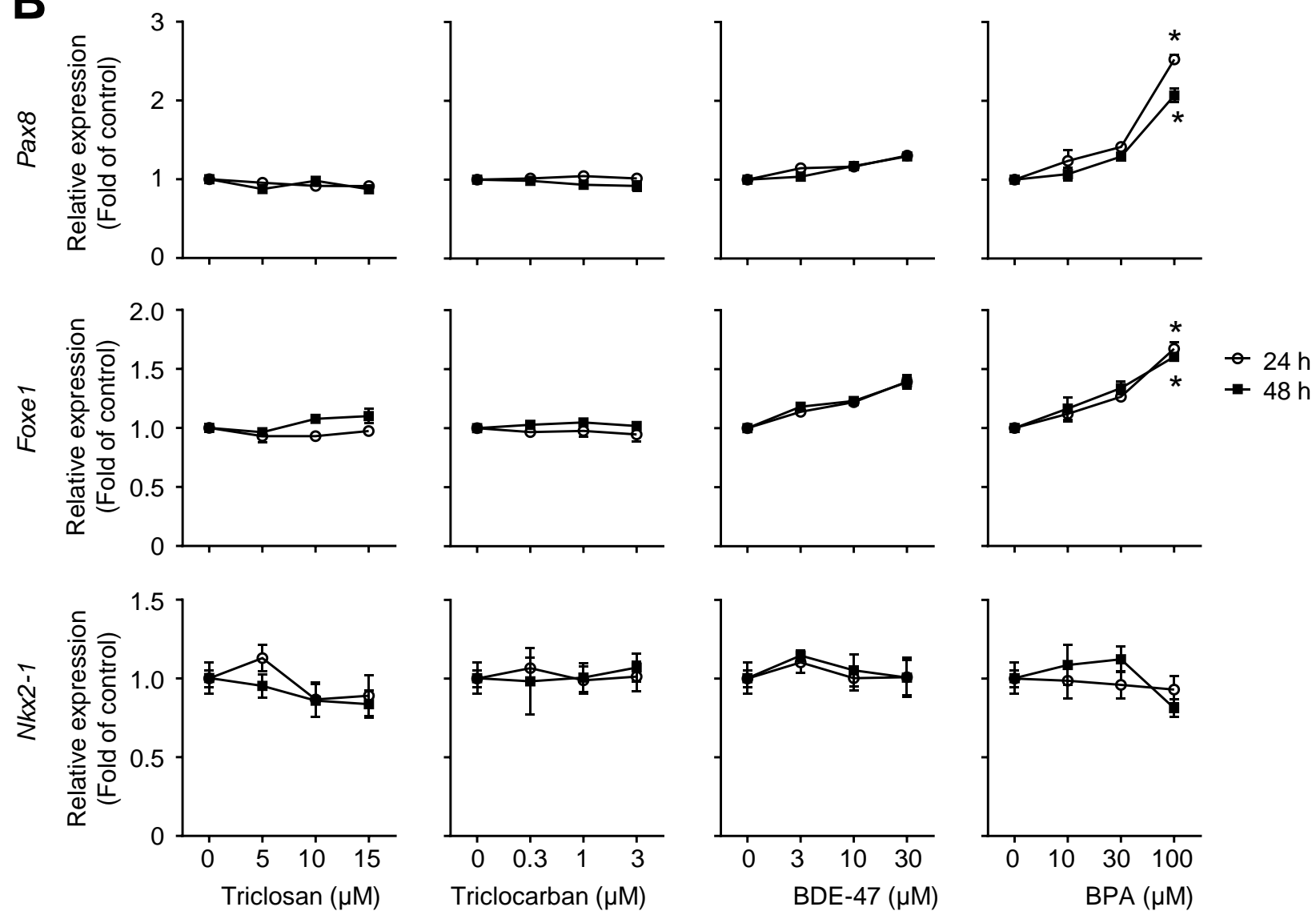
Fig. 6
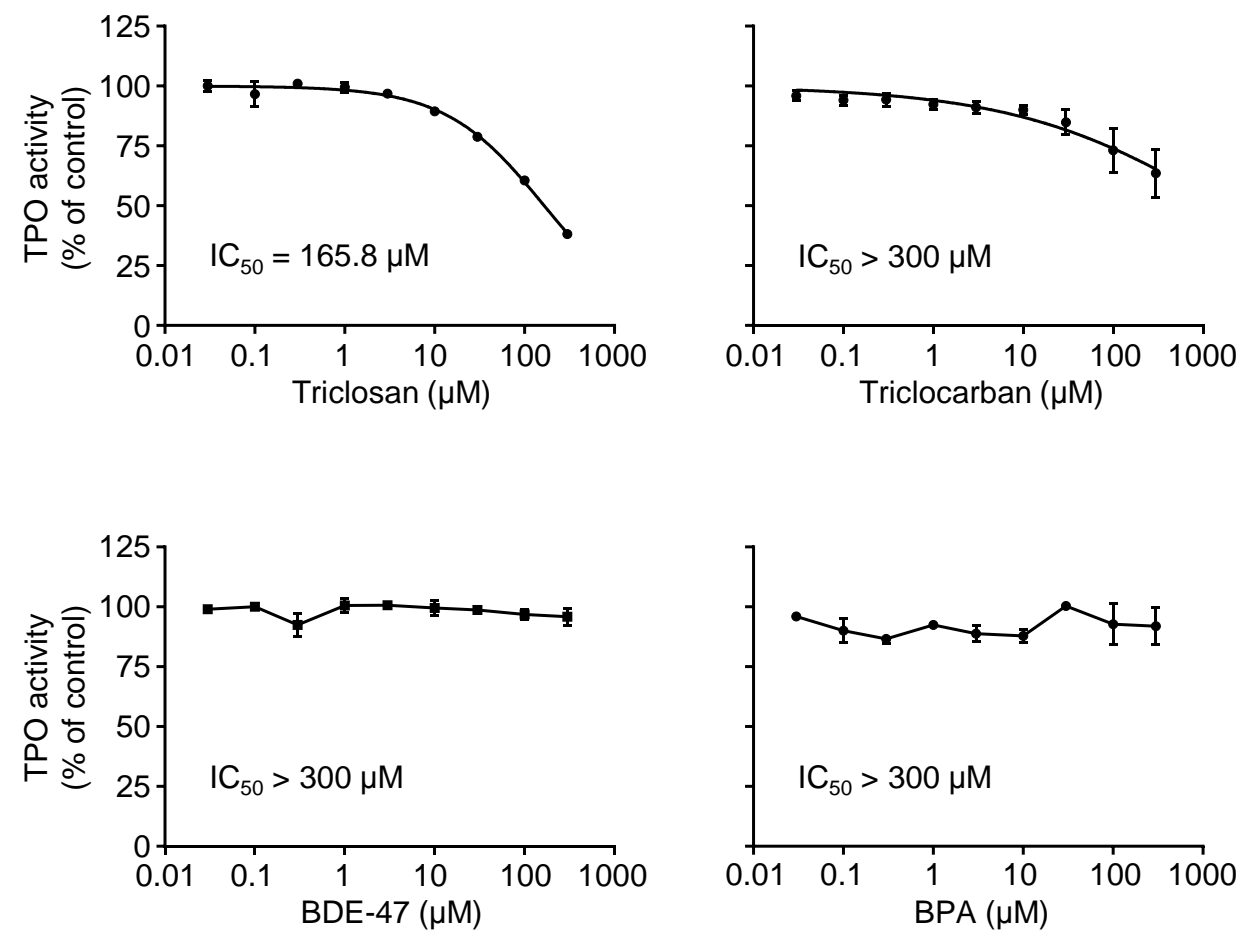


\section{Highlights}

Triclosan, triclocarban, BDE-47, and BPA inhibited iodide uptake in rat thyroid follicular cells. All four chemicals acted as non-competitive inhibitors of the sodium/iodide symporter. The chemicals exhibited differential effects on thyroid hormone synthesis gene expression. Thyroid peroxidase was not a primary target of the four chemicals. 